to the progress of zoological knowledge, Sir William Flower found time to extend very largely among the educated classes an interest in the aims and results of zoology by the willing courtesy with which he received visitors at the Museum in Cromwell Road, and explained its contents. His interest in his work there was so sincere that no zoologist ever asked in vain for his help and advice in museum matters. He was so earnest in carrying out his new devices for the effective exhibition to the public of zoological specimens that even on his busiest days he would find a few minutes to show his latest improvements to one who sympathised with his aims and believed in his methods.

Personally, I owe very much to him in this way. I am glad also to be able to acknowledge here the help which he gave to me by supporting in a valuable letter, which was printed and circulated at the time, the re-arrangement of the zoological and anatomical collections in the University Museum at Oxford, which I had proposed and was enabled subsequently to carry out-largely in consequence of the weighty opinion which Sir William Flower gave in its favour.

E. RAY LANKESTER.

\section{THE DUTIES OF PROVINCIAL PROFESSORS}

D URING the past twenty years numerous centres of university education have grown up all over our country, and much public money has been spent in their endowment. Some of these colleges have already risen to the rank of universities with the power of conferring degrees; others are eagerly pressing forward in the same direction in the hope of competing with their more fortunate rivals. If this multiplication of universities is not to result in lowering the prestige of British university degrees, but to enable us to compete in the matter of scientific education with foreign countries, it is of the utmost importance that the professorial staffs of our younger university colleges should be placed under the most favourable positions for establishing the reputations both of themselves and of their colleges in the matter of higher study and research. The time appears to have come when we must face much more boldly than hitherto the question whether the conditions attaching to provincial professorships and lectureships, even in some of our most successful university colleges, are conducive or inimical to progress in such respects.

In calling attention to the serious and, to our mind, unnecessary disadvantages under which provincial professors are often placed at the hands of their Councils or Governing Boards, our remarks must be understood to be based on a considerable number of experiences of which we have gathered details during some years.

A foreign professor may only lecture five hours a week, and devote the rest of his time to research, and yet be regarded as discharging his duties fully and efficiently. Under such a system German professors have filled their class-rooms with the best students drawn from all parts of the world, German degrees are rising in public estimation year by year, English students are going out of their own country for the higher training they cannot obtain at home, and we are mainly indebted to Germany for our standard literature on every branch of science.

In America university development is more recent, but the majority of universities are lavishly staffed with professors and assistant lecturers, who thus have ample time for research ; and the system has been introduced of giving these teachers one free year in seven, in order that they may be able the better to keep themselves abreast with the most recent developments of their science. Under such conditions, America is rapidly pressing forward in scientific research, and American text-books are slowly and surely finding their way into English classrooms.

NO. I 550 , VOL. 60]
As instances of what one university can do in pro moting research, even in a single department of science, we need only call attention to the Communications from the Physical Laboratory of the University of Leiden, published periodically in English, or the Physical Revieze, brought out under the auspices of Cornell University.

Our modern centres of university education are largely bound down to the policy of attracting the greatest number of students, not by the reputations of their professors, but by the attractions they offer in small bursaries and in facilities for cheaply acquiring pass degrees. Under this system a professor may give fifteen lectures a week or more, and spend most of the rest of the day in the laboratory; but there is no limit to the extraneous work required of him by his Council or Governing Board, beyond that research work forms no part whatever of his obligations. We do not deny that good work is done in this country by many provincial professors, but it is often done under extreme difficulties, and many others are debarred from taking that place in the scientific world for which their abilities qualify them.

With regard to the lectures themselves, these are almost exclusively limited by the syllabus of examinations for pass degrees. Matriculation preparation forms a heavy item in the work of most departments, and one to which great importance is commonly attached. It is the duty of the professor not so much to push forward his best students as to adapt his lectures to the requirements of the average student, and to bring as many as possible up to pass standard. $\mathrm{He}$ is held responsible for the attendance and diligence of his students in class, and is bound to make records of these matters ; while out of class he and his colleagues are jointly responsible for general discipline, even extending to the rules of athletic clubs. $\mathrm{He}$ is required to set and correct exercises and examination papers at frequent intervals. If students have not followed his lectures properly he is expected, often at short notice, to provide tutorial instruction without limit to those whose chances of passing are in danger-an arrangement, by the way, hardly calculated to ensure students giving their best attention to professorial lectures.

We do not imagine that any professor, if left to himself, would be wanting in willingness to give a large amount of his private time to helping students over difficulties, and making his lectures convey the greatest amount of instruction with the least amount of work. But if a professor makes a conscientious stand against cramming, or puts any personality into his professorial work, he runs the serious risk of losing at a few weeks' notice the post he has held for years, at the hands of a Governing Board who misinterpret his action because they have no knowledge of the conditions attaching to a sound teaching of his subject. In such cases students, who are more concerned about getting a degree than about the thoroughness of their training, may be called on to give evidence against their professor. We have knowledge of several instances in which colleges have on insufficient grounds lost the services of men who have been doing good work for them, whose teaching has been acknowledged to be successful, and who, under less disadvantageous conditions, would have done them credit by their scientific work.

The practical result of this system is that our modern university centres, whether chartered or not, are devoting their endowments to competing for cheap pass degrees with one another, and with private institutions and tutors who prepare for London University and similar examinations. The students spend the whole day in class-rooms and in laboratories, and when they have done the exercise work required by their teachers, the day is gone and they are too tired to think over what they have learnt. Their professors are thus required to do the thinking for them. 
After three years in the mill the students obtain a degree, gained under conditions calculated to minimise what should be one of the most important features in any university training: the learning to think and overcome difficulties for oneself. There is thus a growing annual output of graduates of both sexes who find, of ten too late, that their qualifications only fit them for one career: that of swelling the ranks of the already overcrowded and underpaid teaching profession. The production of a certain number of schoolmasters is a necessary element in the educational system of every country, but the question is: should this or the advancement of higher learning be the main function of a university endowed with public funds?

Many provincial colleges plead poverty as an excuse for overburdening their staffs with pedagogic and tutorial work. But these colleges are not too poor to vie with each other in the award of small scholarships, many of which go to pass students of no great ability. And experience, both in America and in this country, has shown that if only such objects as endowment of research are prominently brought before public notice, support will not be found wanting.

In conclusion, the directions where reform is most needed include the following :-

(1) Discontinuance of matriculation preparation-work which naturally belongs to the province of schools and crammers.

(2) Recognition of research work rather than tutorial instruction of pass candidates as the main duty of a professor outside his class-room.

(3) Reduction of the hours of class work, both of teachers and students.

(4) Revision of the now precarious conditions under which provincial appointments are tenable.

(5) Attraction of public attention to the importance of providing facilities for professorial research.

(6) The appointment of more and better paid assistantlecturers and demonstrators.

(7) A more judicious expenditure of scholarship money, which should be restricted to honours students.

If the new university systems of this country are not, in the course of a few years, to take a subordinate position, and their degrees to sink into disrepute, if, in short, we are not to be left in the lurch by our foreign rivals, it becomes the duty of all who are responsible for the management of our provincial colleges and universities to have their attention aroused to a state of affairs which too often results in their professors being sweated and their students crammed.

\section{GOVERNMENT GRANT IN AID OF ANTARCTIC EXPLORATION.}

$\mathrm{THE}$ following letter, referring to a Parliamentary grant in aid of Antarctic exploration, has been received by Lord Lister from H.M. Treasury, and sent to us by the Secretaries of the Royal Society :--

Trexsury Chambers, July 3, 1899 .

My LORD,-I am directed by the Lords Commissioners of Her Majesty's Treasury to inform you that the First Lord has laid before the Board the memorial signed by your Lordship as President of the Royal Society, by the President of the Royal Geographical Society, and by other distinguished representatives of various branches of science, by which memorial application is made for a Government grant in aid of the expedition now being organised by the Royal Society and the Royal Geographical Society for the exploration of the Antarctic regions. This application has received the careful consideration of Her Majesty's Government, and I am directed to inform you that they are prepared to ask Parliament for grants amounting, in all, to $45,000 l$. NO. I 550 , VOL. 60] towards the expenses of the proposed expedition, provided you are able to assure them that not less than an equal amount will be forthcoming from other sources, so as to enable the scheme to be efficiently carried out.

In making this announcement, I am to call attention to the latter part of the speech of the First Lord to the deputation which waited on him on this subject, as indicating that Her Majesty's Government must not be regarded, in making this promise, as inaugurating a new era of more extensive grants than formerly from the Exchequer in aid of scientific enterprises. Rather, it is to be understood that the very exceptional importance of the present scheme, so strongly represented by the deputation, is being recognised by the promise of a special grant.

At the present time, it is only necessary to add that the applications to Parliament for instalments of the grant will be spread over four years, of which 1900-1901 will be the first.

I am to ask you to be so good as to communicate this decision to the other signatories of the memorial. I am, My Lord, (Signed) FrancIS MOWATT.

LORD LISTER, President of the Royal Society, Burlington House.

\section{NOTES}

THE Paris Academy of Sciences has been authorised to increase its number of national and foreign Correspondants from 100 to I 16.

THE British Medical Journal announces that Sir John Burdon Sanderson, Bart., and Prof. Michael Foster, K.C. B., will be entertained at dinner by British physiologists on July 20 , to congratulate them on the honours recently conferred on them by the Queen. The dinner will take place at the "Star and Garter," Richmond.

THE Volta Centenary Exhibition at Como, described in NATURE of June 22, has been completely destroyed by a fire, attributed to the fusing of some electric wires. Practically all the precious Volta relics were lost in the flames, notwithstanding the precaution taken to preserve the objects by placing them in a receptacle of solid masonry. The only things saved were a sword of honour presented by Napoleon the First to Volta, a picture by Bertini of Volta explaining his battery to Napoleon, a cast of the great electrician's skull, his watch, and a few personal relics. Volta's books and manuscripts, some of which were recently bought by the Italian Governmer for 100,000 lire, his collection of batteries, the only authentic portrait of Volta, his will, \&c., were all destroyed. In spite of the destruction of the Exhibition, the committee has decided that the fêtes in honour of Volta shall be continued. The International Congress of Electricians will be held as previously arranged.

Prof. Ewar'r exhibited a number of his zebra hybrids, their dams, sire, and half-brothers and sisters, at the great Agricultural Show recently held in Edinburgh. The authorities were little prepared for the interest taken in the exhibit, with the result that many thousands either falled to see anything of the hybrids, or had but a passing glance. The Prince of Wales, accompanied by a deputation of the Royal Agricultural Society of England, made a special inspection of the mixed family. From a contemporary we learn the Prince was so greatly interested that he requested Prof. Ewart to make a similar exhibition next summer at the Royal Agricultural Societies' Show at York. Should breeders give up empirical in favour of scientific methods, not a 